\title{
OUR TEACHERS: COLLECTED MEMORIES OF PRIMARY EDUCATION IN DERB YSHIRE SCHOOLS FROM 1944 - 2009
}

\author{
Fiona Shelton \\ Centre for Excellence in Learning and Teaching, University of Derby (United Kingdom)
}

\begin{abstract}
This paper presents findings from narrative interviews undertaken with 24 narrators who attended primary school in the decades from 1944 - 2009. Deductive themes were first selected by examining the quantity of content and relevance to the study. Four deductive themes were drawn from the narrators' recollections: Our Teachers; The Lessons We Learned; Our Friendships and the Games We Played and finally The Books we Read. The focus of this paper is on the findings from one of the deductive themes: Our Teachers. Once the stories had been transcribed, they were analysed for inductive themes. These were identified as: Pupil-teacher relationship, noted across each of the decades. A gendered workforce, reflected in each decade, except 1999-2009. Teacher personality was common across all decades. Corporal punishment was common in the decades from 1944-1987, but not present after 1987. Finally, Teacher professionalism was a prevalent theme in most decades except 1999-2009. Key findings related to the connections that come with the relationship the teacher forms with their pupils. Teachers who break the mould are well remembered by pupils. The nature of the primary school workforce has changed since 1944, and is now female dominated. Because of changes to legislation, the role of the teacher has evolved, the changes in professional behaviour are noted in the narrators' stories, from decade to decade.
\end{abstract}

Keywords: Memories, education, teachers, schools, narrative.

\section{Research context}

In this paper, I share findings from one of the deductive themes from a larger piece of research, which utilizes narrative inquiry to understand people's personal perspectives on the phenomena of their experience at primary school. The overarching aim of the research was: To understand the changing nature of primary education in Derbyshire schools through the stories of those who have experienced it over 65 years from 1944 - 2009. There were 24 participants, male and female, four from each decade, 1944-1954, 1955-1965, 1966-1976, 1977-1987, 1988-1998 and 1999-2009. These participants attended different types of primary schools: two from state schools, one from a church school and one from a private school in each of the decades. There were four research questions:

1. How do narrators from different decades discuss primary schooling?

2. What were the key themes identified from the stories?

3. How do narrators' stories reflect the policy, literature and social context of the era?

4. How do stories of primary school help us understand educational identity?

The research questions provided a platform to explore the application of narrative to understand how narrators from different decades discuss primary school, in relation to a number of themes. Additionally, the research questions presented an opportunity to understand further, how the stories reflected the political and social context of the time, as well as gaining a better understanding of the educational identity of the narrators. The names of the teachers have been changed for ethical purposes; the names I have given to the teachers are reflective of the personalities described by the narrators.

This paper presents findings from some of the narrative interviews undertaken with the 24 narrators. The narrators all gave permission for their names to be used in the research study, when a narrator is cited, the dates in brackets denote the decade that they attended primary school. Deductive themes were first selected by examining the quantity of content and relevance to the study. There were four deductive themes drawn from the narrators' recollections: Our Teachers; The Lessons We Learned; Our Friendships and the Games We Played and finally The Books we Read. The stories were then analysed for inductive themes, presented later in the paper. The focus of this paper is on one of the deductive themes: Our Teachers. 


\section{Our teachers}

Teachers are at the heart of every school. Many of us remember our favourite teachers, we remember why we liked them and we remember those we liked less well. In the narrators' stories, we see teachers described in many ways and we can see why and how they are remembered. In this research strand, we see how the role of the teacher is varied and how teacher behaviours change over the decades, often alongside the changes in policy and legislation. We see a shift in the teaching profession reflected in the societal expectations and changes over time. The stories demonstrate the influence teachers have on pupils' lives, how their words and deeds have a lasting memory with the narrators. There is a clear picture of how the role of the teacher changes as we move through the decades and how the profession has changed since 1944. I first present the inductive themes, and extracts from the narrators' stories highlighting these themes, with discussion in relation to the social and political context woven through the paper.

\section{Inductive themes}

Once the stories had been transcribed, they were analysed for common themes. These were identified as: Pupil-teacher relationship, noted across each of the decades. A gendered workforce, reflected in each decade, except 1999-2009. Teacher personality was common across all decades. Corporal punishment was common in the decades from 1944-1987, but not present after 1987. Finally, Teacher professionalism was a prevalent theme in most decades except 1999-2009.

\subsection{Pupil-teacher relationship}

There has been much research which illustrates why effective relationships are key for good learning to occur (Muller, 2001; O'Connor, Dearing and Collins, 2011; O'Connor, Collins, and Supplee, 2012) this relates to forming attachments for academic and social adjustment and how good classroom relationships can provide a stable platform for progression through the school years. Effective teachers engage in practice which creates a positive climate for learning (Shelton, 2016). Coe, Aloisi, Higgins and Major (2014) discuss the importance of the quality of interactions between teachers and students, the expectations of teachers and the need to create a classroom that is constantly demanding more, whilst still recognising student self-worth.

In the 1950s and 1960s, school was very different for children to the classrooms of today. During the 1950s, there was a teacher recruitment crisis, with more children being born post-war, these were the 'baby boomers'. Classroom sizes were larger than in most classrooms today, the narrators in these decades often reported on a distance between the pupils and the teachers, which give an indication to the nature of classroom interactions.

Jean (1944-1954): "They were nice but they were very remote, they were the teacher, they were treated with respect and we were just the children that they taught."

A key part of the positive interactions is how the narrators remember their teachers showing an interest in them. Andy and Tony both recall the teachers they liked, because of the interest shown in them, Bruner (1991) referred to canonicity and breach, the idea of breaching the canon relates to the ways that narrators remembered where their teachers had broken away from the archetypal teachers they knew. These teachers 'breached the canon' of the time and this is likely to be why they were remembered so well. In the recollections of those narrators from 1944-1976, those breaching the canon were likely to be the teachers that were well liked. Narrators from the more recent decades tended to report on breach of canon of those teachers whom were disliked:

Andy (1955-1965): "And then we went up to Mr Marvel's class, I think he was the best and most up to date teacher there. And he was really nice and and I remember us being in that classroom and being very happy there. He was the one who always took us to football and cricket and things like that..."

Tony (1966-1976): "I always used to like Mr Wright. He did songs and we did maths with him. He cared about us."

Getting on with teachers is important for healthy development and progress through school, some pupils are quick to learn this and play the games of the classroom (Waters, 2013), conforming to the expectations laid out by the teacher.

Chloe (1999-2009): "I liked having good relationships with my teachers and felt that it was advantageous to have teachers who liked you and wanted to push you to achieve your best."

There are of course relationships that are loss positive as experienced by Emily.

Emily (1977-1987): I think my year 3 and year 5 teacher got me and enjoyed me, my year 4 teacher did not, my year 6 teacher seemed pretty indifferent." 


\subsection{Gendered workforce}

Leading up to the 1950s, the teaching profession was male dominated at both the primary and secondary phases. This was evident in the descriptions the narrators gave of the schools, with some, for example, making reference to the headmaster.

David (1944-1954): "There were four teachers, a headmaster and a secretary..."

Jean (1944-1954): "A lot more men then, than there are now, the headmaster was male.

Val (1944-1954): "There were only two teachers... One in the juniors and there was one in the infants and old Mr Jones was the Headmaster..." interesting."

David and Kevin (1955-1965): "Strange enough I liked Mr Gamble, headmaster, I found him

Simon (1966-1976): "And the headmaster seemed like he was ancient..."

Jon (1977-1987): "He went on to be headmaster..."

With much discourse over the last 20 years on the feminisation of the primary school, the gendered nature of primary schools has changed in the current educational context. Whilst males do not dominate the primary workforce today, it is still a gendered workforce, but now female dominated, with $82.4 \%$ female teachers at primary school level in the UK, a proportion that is steadily increasing (British Educational Suppliers Association, nd).

\subsection{Teacher personality}

The personality of teachers was a theme that resonated across all the decades. This was evident in the way the narrators described their teachers and is reflected in the names that I have given to the teachers in protecting their identity. This theme correlates to the pupil-teacher relationship theme because those that created a classroom climate for learning, which was conducive to the narrators enjoying school, were remembered for that. Conversely, those who ruled by making children fear them, or those who could not manage their classrooms well were remembered for being unkind or 'off the wall'.

Remembering his teachers' personalities, Nic (1966-1976): "Yeah the teachers were, with the exception of one or two, slightly eccentric characters not in the way of dangerous or abusive, but you know, looking back to the standards of the 60 s the regime was reasonably liberal and teachers were quite sensitive."

And Suzanne (1977-1987): "Loved them, absolutely loved them at the time, really, you always knew that there were ones that were slightly stricter than others and you knew who they were but they were all really lovely and they had a lot of time and clearly in hindsight really dedicated to what they were doing."

Amy (1988-1998): "So yeah. I remember that my teacher was really creative, and I remember I wanted to be her when I was older, and we did quite a lot of fun stuff mixed in with that."

Theresa (1988-1998): "I remember Miss Wild who looked like she'd been electrocuted, because she was so nice but really strange. Miss Super, because she was younger and the cool teacher and played netball..."

Nathan (1999-2009): “...Mrs Noun ... my English teacher, and she was also the leader of the school play, I was always a really, really shykid... Mrs Noun was probably the one who involved me in things the most, who told me to audition for this school play... she was kind of the one who brought me out my shell a little bit, and helped me to express myself a little bit more."

Nathan's story shows how teachers can have a positive impact on our lives, they can influence us to aspire to things we did not know we were capable of achieving. Good teachers are at the heart of effective schools and quality of instruction is at the heart of all frameworks of teaching effectiveness (Coe et al, 2014).

\subsection{Corporal punishment}

During the 1940s, 50s and 60s, class sizes were large due to the numbers of babies born after the war and there was crisis in teacher recruitment. To keep children in line, teachers were often very strict, it was common for a child to be rapped over the knuckles, on the buttocks or on the palm of the hand with a ruler (Castleow, nd).

Corporal punishment was commonplace in schools, children were often 'controlled' by fear. Corporal punishment gave teachers the opportunity to exercise their power with items such as slippers, canes and rulers. There were no common rules across schools, so misdemeanours would be tantamount to five lashes of the cane for instance, whereas other might get five lashes for much more serious transgressions.

Andy (1955-1965) tell us: "Mr Cordial who was very genial, I remember him always having a smile on his face even when he used corporal punishment. He didn't hurt you on the backside, he never used a cane he used a ruler. A relatively minor misdemeanour was one ruler used on your palm half a dozen times. Next stage was to use about four rulers and bend them back and let them whack down onto your 
palm. Then next stage demeanour was hand over, and the edge of the ruler hit on your knuckles - that used to come keen but I loved him, I really liked Mr Cordial."

Tony attended a church school; he recalled how the nuns could be harsh.

Tony (1966-1976): "I think two or three particular nuns who were teachers at the time... you knew you'd steer clear of really, because they would be dragging you off into the headmistress's office, who was a nun - and she wouldn't stand there and take any explanations from you at all. She'd just dish out the cane, or whatever."

The strictness of the nuns is a clear and lasting memory for Fran, she remembered their harshness vividly and her descriptions depict a hard, frightening classroom where the nuns ruled with severity, chastisement and canes. I felt a strong sense of justice when Fran recalls the time she stood up to the nuns, although she was met with an even more frightening threat.

Fran (1944-1954): "I was told off all the time for talking, and I was threatened with the cane and I happened to say I don't think nuns should use canes, and they told me "Fran, if you say that again I've got five canes and I'll use them all on you'.... I did suffer the most terrible, awful nightmares where even when I woke up I could not get rid of this feeling of fear. I'm still very anxious and I'm sure it's goes back to that fear."

David and Kevin (1966-1976): “... if you'd done something wrong fair enough, Mr Brandish'd give you a slap and that'd be it and it didn't carry on..."

Rosemary (1966-1976): "...the teacher, her name was Mrs Good-hand, but we called her Mrs Bad-hand because she was very, very stern. She would smack you around the back of the head, we did as we was told."

Corporal punishment was permissible in schools in England until it was banned in state schools in 1987. The professional nature of teaching has increased over time with standards produced for professional behaviour. The introduction of The Teachers' Standards, in 2007 and updated in 2011, define the minimum level of practice from trainees and teachers from the point of being awarded qualified teacher status, and are applicable to all teachers who are appraised under the 'The Education Regulations' (Department for Education (DfE), 2011). One of the standards states that teachers must 'establish a safe and stimulating environment for pupils, rooted in mutual respect' (DfE, 2011: 10). Our contemporary classrooms, and the teachers who teach in them, are therefore now bound by a professional code of conduct. Positive behaviour management techniques are promoted and encouraged by school leaders and inspectors.

\subsection{Teacher professionalism}

Teaching has developed as a profession since 1944. Le Grand (1997) suggests that there was a so-called 'golden age of teacher control' from 1944 to the mid-1970s. During this time, parents of children in state schools were expected to trust the professionals and accept that teachers knew what was best for their children (Whitty and Power, 2000). This is in stark contrast to the education system as we know it today in England. The government makes key decisions about schools, and teachers are highly accountable to the Office for Standards in Education (Ofsted) and for the delivery of the curriculum, exam results, children's progress and school improvement. Up until the 1970s the state did not seem to want to intervene, even though effectively it paid teachers' salaries. From the mid-1970s to the current day there has been increasing intervention from the government in education. Arguably, the autonomy afforded to teachers has diminished, with greater compliance expected in relation to outcomes, testing and curriculum delivery.

Teacher professionalism has evolved with the Teachers' Standards (Department for Education, 2011), teachers are bound by a professional code of conduct that must be evidenced leading up to qualification and upheld throughout their career. Examples of unacceptable teacher behaviour can be evidenced by stories told by some of the narrators attending school prior to 1970 .

David and Kevin, (1955-1965): "Mrs Gamble used to send you down to the shops for her fags. You were basically her lackey." In our education system today, it is hard to believe that children would be sent to the shops to buy cigarettes for their teacher. Emily also shares a story that would now be defined as unprofessional behaviour.

Emily (1977-1987): "Least favourite was Mrs Loathsome, she was bat shit crazy. Brushed her teeth in the middle of lessons, ate 'Crunchies' while we all did silent reading, had a heater facing her desk and the classroom was bloody freezing in the winter." Again, Bruner's (1991), canonicity and breach can be seen in these recollections. The younger narrators, those attending school from 1988, also remember teachers who did not fit the mould, but stories of unprofessional behaviour are not evident in their narrations, it is likely that this is a result of The Teachers' Standards (2011). 


\section{Conclusion}

It seems evident that what the narrators remembered are the connections that come with the relationship the teacher forms with their pupils. The narrators tell us about the people these teachers were, their personality and what it was about them, as people that they liked and disliked, when they were pupils in their classes. The narrators are fond of those teachers who helped them to learn, those whom showed an interest in them and those whom they looked up to. Teachers who break the mould are also well remembered by pupils, the narrators particularly remembered those teachers who are eccentric, unkind or different. The nature of the primary school workforce has changed, males do not dominate the primary workforce today, but it is still gendered, it is now female dominated, as reflected in the statistics presented. The stories told by the narrators demonstrate how teaching has changed considerably since 1944 and this is reflected in the recollections. The nature of behaviour management and therefore the classroom interactions has changed in schools since 1987, when the ban on corporate punishment was first introduced. Because of changes to legislation, the role of the teacher has evolved and the memories of how teachers are recalled seem to change over time. Of course, it is important to recognise that time plays a role in the way we remember, our stories can lose richness of detail and stories are often embellished as they are told and retold. However, regardless of this, it is clear that teachers are remembered for their personalities, the relationships they form with pupils and their classroom interactions, all fundamental to support student progressiona and achievement.

\section{References}

British Educational Suppliers Association. (nd). Key UK Education Statistics. Available from: https://www.besa.org.uk/key-uk-education-statistics/ accessed March 2019.

Bruner, J. (1991). 'The Narrative Construction of Reality'. Critical Inquiry. 18(1): 1-21.

Castleow, E. (nd). Schooldays in the 1950s and 1960s. Historic UK. Available from: https://www.historic-uk.com/CultureUK/Schooldays-in-the-1950s-1960s/ Accessed: February 2019.

Coe, R., Aloisi, C., Higgins, S. and Major, L. (2014), What makes great teaching? Review of the underpinning research, The Sutton Trust. Available from: http://www.suttontrust.com/wpcontent/uploads/2014/10/What-Makes-Great-Teaching-REPORT.pdf. Accessed: January 2019.

Department for Education, (2011). Teachers' Standards Guidance: for school leaders, school staff and governing

bodies. London: Crown Copyright.

Le Grand, J. (1997). Knights, knaves or pawns? Human behaviour and social policy. Journal of Social Policy. 26(2), 149-169.

Muller, C. (2001). The role of caring in the teacher-student relationship for at-risk students. Sociological Inquiry, 71(2), 241-255.

O’Connor, E.., Dearing, E., and Collins, B. (2011). Teacher-child relationship and behavior problem trajectories in elementary school. American Educational Research Journal, 48(1), 120-162.

O'Connor E, Collins B, Supplee L. (2012). Behavior problems in late childhood: The antecedent roles of early maternal attachment and teacher-child relationship trajectories. Attachment and Human Development: 14.

Shelton, F. (2016), Teacher Quality and Effectiveness: Challenges and Opportunities, in Holz, (2016). Aleksandrovich, M and Zolowek, H. (2016) Current Trends in Higher Education in Europe, Aktuelle Entwicklungstendenzen im europaischen Hochschulwesen, Munich: Lit Verlag.

Waters, M. (2013). Thinking Allowed on Schooling. Carmarthen: Independent Thinking Press.

Whitty, G. and Power, S. (2000). Marketization and Privatization in Mass Education Systems. International Journal of Educational Development. 20: 93-107. 